\title{
Religiões, cristianismo e a busca de uma terra habitável
}

\author{
Religions, cristianism and a search for an inhabitable earth
}

\section{Afonso Maria Ligorio Soares*}

Pontifícia Universidade Católica de São Paulo (PUC-SP), São Paulo, SP, Brasil

\section{Resumo}

Este artigo visa refletir, do ponto de vista da teologia cristã, sobre a contribuição das religiões na busca de uma terra habitável. 0 autor parte das recentes discussões sobre sustentabilidade para, em seguida, ampliar a discussão para a questão das identidades e relações interpessoais no nosso lar planetário. 0 apuro hermenêutico que conduz a análise tem por referencial teórico de fundo as categorias teológicas de J. L. Segundo.

Palavras-chave: Sustentabilidade. Religiões. Sincretismos. Soteriologia. Diálogo.

* AMLS: Doutor, e-mail: sofona@uol.com.br 


\section{Abstract}

This article wants to reflect, from the Christian theology point of view, about the role of religions in search of a livable land. The author starts from the recent discussions about sustainability and, in sequence, discusses the question of the identities and interpersonal relationships in our planetary home. The hermeneutical care that leads to the analysis is the theoretical framework of the theological background categories of J. L. Segundo.

Keywords: Sustentability. Religions. Syncretisms. Soteriology. Dialogue.

\section{Introdução}

Este texto foi finalizado sob o impacto da inédita crise de abastecimento hídrico vivida em alguns estados brasileiros, beirando o colapso em certas regiões. De outra parte, a polarização verificada no último turno das eleições presidenciais (2014) trouxe de novo à tona o fantasma dos extremismos de direita e de esquerda, ao mesmo tempo em que se vive, na cúpula da Igreja Católica, uma fase de distensão e retomada de diálogos impensáveis até há poucos anos. Um quadro complexo que torna ainda mais movediço o terreno que este artigo pretende trilhar. Afinal, sugerir qual seja o papel das religiões na busca de uma terra habitável é, por si só, um tremendo desafio, que só pode ser enfrentado pelas próprias tradições religiosas no cotidiano de suas reinvenções a partir dos distintos contextos em que se (re)inserem. Pode-se, contudo, com deliberada prudência e maior proveito, cumprir a tarefa no melhor estilo dos antepassados bíblicos de judeus, cristãos e muçulmanos: olhar a trave do próprio olho e colocar-se à escuta dos depoimentos dos vários sujeitos envolvidos. E, quem sabe, essa assumida referência cristã como ponto de partida poderia inspirar adeptos de outras religiões a fazerem o mesmo em suas respectivas tradições a fim de juntos contribuirmos para tornar este mundo mais habitável. 
Os últimos 15 anos viram crescer no pensamento teológico cristão uma reflexão engajada que tem procurado responder (ou, ao menos, formular melhor) as seguintes questões: nosso mundo é sustentável? Mas a quem interessa que este mundo se sustente: às pessoas comuns ou às empresas e seus negócios? Nosso mundo tem salvação? Que espécie de problema suscita que busquemos salvação para ele?

Uma soteriologia ecológica, como sugere o teólogo L. C. Susin, deveria ir além do que comumente entendemos por problemas ambientais. Talvez coubesse aqui a maneira original como Juan Luis Segundo lidava com a categoria ecologia/ecológico ${ }^{1}$. Isso ampliaria a discussão para a criação de uma sociedade realmente fraterna - no melhor sentido dessa utopia - em que, para dizê-lo com Hugo Assmann, todos coubessem.

Uma terra habitável terá pessoas que dialoguem a partir de suas tradições religiosas em direção às demais tradições. É inclusiva e acolhe o diferente, começando ad intra. Portanto, nessa terra cabem as comunidades queer? As mulheres terão aí plena cidadania? Homens e mulheres negros terão pleno acesso a educação, trabalho e salário justo? A realidade do sincretismo ou da dupla pertença religiosa - como a afro-católica - será respeitada? Os interesses e questionamentos da juventude serão acolhidos nas velhas e milenares religiões - sem com isso descartar a sabedoria anciã?

\section{Sustentabilidade da Vida e Espiritualidade}

Comecemos então por um tema que vem se mantendo na ordem do dia há alguns anos. A Soter (Sociedade de Teologia e Ciências da Religião) abordou, em recente Congresso Anual, justamente o tema da Sustentabilidade da Vida e Espiritualidade ${ }^{2}$. Seu objetivo na ocasião foi reunir pesquisadores que fornecessem dados e categorias de análise para, num debate interdisciplinar, do ponto de vista teológico e das ciências

Cf., por ex., SEGUNDO, 1985.

20 Congresso transcorreu de 7 a 10 de julho 2008, em Belo Horizonte, MG. Para as conferências principais, veja: SOTER, 2008. 
sociais da religião, repropor de forma ampla a questão da sustentabilidade integral da vida no planeta e suas implicações nas culturas e religiões de nossos povos.

Pelo que se pode ver dos trabalhos publicados no livro impresso ${ }^{3}$ e no segundo volume, contendo os Anais do Congresso ${ }^{4}$, não foi fácil abordar um tema tão grave e urgente de maneira ecológica e plural, acolhendo contribuições do âmbito das religiões, da política, das ciências da vida e da saúde, numa discussão atenta à complexidade que o assunto comporta. Mas ao menos os trabalhos resultantes tiveram, em sua maioria, a preocupação por um tratamento apropriado da questão da sustentabilidade do planeta e da qualidade de vida de seus habitantes, sem resvalar para a reprodução de velhas ideologias de direita ou esquerda nem se acomodar a palavras de ordem ou bandeiras superficiais na abordagem dos desafios.

O fato de estarmos usando e abusando de metáforas - sustentabilidade, por exemplo - cujo uso é cooptado por grandes grupos empresariais transnacionais, já ficou claro desde a conferência inicial do Congresso da Soter, e do capítulo de abertura do livro correspondente, a cargo da geógrafa prof ${ }^{a}$ Maria Adélia Aparecida de Souza (A geopolítica do desenvolvimento sustentável: panorama mundial). A autora há anos vem trabalhando o papel do uso das metáforas e das ideologias no trabalho científico. Segundo a contundente reflexão da autora, não se trata de compreender a geopolítica do desenvolvimento sustentável empiricamente, mas de buscar os fundamentos teóricos e metodológicos para o desenho da geopolítica do poder hegemônico existente no mundo. Para ela, ambiente e desenvolvimento sustentável são falsos problemas de investigação. O que devemos investigar são os processos geográficos e geológicos interagentes, especialmente aqueles sobre os quais a sociedade pode ter controle. A questão ambiental e o desenvolvimento sustentável constituem-se em

3 Cf. nota anterior.

4 Foi publicada a versão on-line dos Anais do $21^{\circ}$ Congresso Anual da Soter 2008. Veja 0 link: <http:// ciberteologia.paulinas.org.br/portals/44/LivroDigital.pdf>. 
metáforas e ideologias nas quais se fundamenta o discurso que sustenta, hoje, o modo de produção capitalista ${ }^{5}$.

O sociólogo Pedro A. Ribeiro de Oliveira trilhou, de certa forma, a vereda aberta pela prof ${ }^{a}$ Maria Adélia, ao tentar combinar os conceitos de consciência planetária, ecossocialismo e cristianismo (SOTER, 2008, p. 6387). O autor tem sua base teórica na perspectiva sociológica, mas em vez de tratar o tema como um objeto, assume uma visão interna à consciência planetária que propõe novos comportamentos e atitudes capazes de assegurar a vida humana em harmonia com a vida do planeta. Nesse sentido, Ribeiro de Oliveira ensaia uma ecossociologia que, embora tateante, se impõe em vista da gravidade da situação do planeta.

Não menos crítica foi a contribuição da teóloga Anete Roese. No texto Ecofeminismo e sustentabilidade (SOTER, 2008, p. 135-172), a autora recolhe argumentos para inferir que a crise ecológica é a crise de um modelo de civilização que se fez, inclusive, graças a certa interpretação e concepção da imagem da criação propagadas pela teologia cristã. O cristianismo não possui, segundo ela, um saldo positivo quando o assunto é a contribuição da religião para uma terra habitável. O que a corrente ecofeminista faz é, portanto, trazer ao debate a relação entre a violência ambiental e a violência de grupos humanos entre si. Ela analisa os fundamentos desta crise, os modelos e sistemas que estão na origem da crise e o que isso representa.

As contribuições de Boff e Susin deram o tom mais acentuadamente teológico do Congresso. Boff sugeriu que a anunciada tragédia do planeta, embora bastante provável, não precisa ser fatal. Para reverter a rota, seriam importantes alguns marcos para uma nova moralidade baseada não apenas numa racionalidade mais holística e cordial, e sim numa nova espiritualidade que, independentemente de qualquer pertença religiosa, se apresente como dimensão profundamente humana (BOFF, 2008, p.

5 Cf. SOTER, 2008, p. 15-37. Na seqüência, o ensaio do prof. Afonso Tadeu Murad, Paradigma ecológico: gestão e educação ambientais (pp. 39-62), caminha numa direção quase oposta ao da prof ${ }^{a}$ Maria Adélia, e apresenta uma chave de leitura para o tema da ecologia em vista do diálogo com a fé cristã e a teologia. Ele mapeia o núcleo central da ecologia, de onde se desdobram dois importantes conceitos: educação ambiental e gestão ambiental. Por fim, sugere alguns possíveis pontos de contato entre a ecologia, a fé cristã e a teologia. Mas não contesta em bloco o conceito de "sustentabilidade" em si mesmo. 
173-190). Susin (2008, p. 191-214), por sua vez, engatinhou uma teologia da sustentabilidade. Assumindo que spiritualitas quaerens intellectum, o autor perguntou-se logo no início se a "leveza" da espiritualidade e a sua elaboração teórica (a teologia) possuem algum peso quando se trata da salvação da Terra (2008, p. 196). Ele se propôs a respondê-lo, sem, porém, fazer uma apologia da teologia, mas antes convidando teólogas e teólogos a uma modesta e convicta contribuição num necessário trabalho interdisciplinar. O resultado dessa união de forças poderia estribar numa soteriologia ecológica, a saber, num trabalho criativo, cuja necessária e complexa interação das três formas de exercício da pessoa (alteridade, reciprocidade e maternidade) concorreria, com inspiração cristã e medida humana, para a sustentabilidade ${ }^{6}$.

\section{Soteriologia ecológica}

Tendo em mente essa proposta de Susin de uma soteriologia ecológica a ser construída, queremos retomar aqui as discussões de um Simpósio Ecumênico Internacional que teve lugar em 2003. Reunidos em Belo Horizonte, teólogos e teólogas brasileiros, franceses e alemães nos propusemos a debater juntos os caminhos da fé cristã neste início de século. "Risquer la foi dans nos sociétés" foi o lema do evento.

O encontro foi muito rico, principalmente por ajudar a quebrar certos paradigmas, já que, como dizia J. Estermann, um dos painelistas do Simpósio,

para muchos teólogos europeos, América Latina sigue siendo un continente vibrante, con una teología comprometida con los grandes problemas sociales, políticos y económicos, con comunidades de base muy vivas, en fin: como un continente eminentemente católico en un sentido más político que espiritual. Para sus colegas en América Latina, la teología

6 Numa visão bem mais pessimista - ou realista - do que nos aguarda, o filósofo John Gray afirma que vem aí a Era Eremozóica, a Idade da Solidão, quando os humanos se apropriarão de bem mais da metade da matéria orgânica do mundo. Mas na visão anti-humanista de Gray, esse homo rapiens é uma espécie que não merece ser preservada e, cedo ou tarde, será extinta, pelo bem da vida na Terra (GRAY, 2005, p. 164-166). 
europea sigue teniendo prestigio y un cierto grado de seducibilidad, pero también como un quehacer demasiadamente académico e intelectualista, y las iglesias son consideradas como empresas que administran el patrimonio cristiano sin entusiasmo ni mayor compromiso político (MÜLLER; VILLEPELET, 2005, p. 73-74).

Estermann continuava dizendo que só teríamos a ganhar se perdêssemos o medo e nos dispuséssemos a aprender uns com os outros. Porém, superação das diferenças que nos separam não é melting pot. A pluralidade não é eliminável, mas deve ser fonte e motor de um diálogo intercultural teológico. "Tenemos que mantener la curiosidad por la alteridad", concluía o autor.

Essa memória do referido Simpósio faz pensar que o papel das religiões na busca de uma terra habitável é bem mais que um projeto de gestão ambiental ou de protesto contra as queimadas em nossas florestas, embora inclua tais discussões. Uma terra habitável precisa, por exemplo, de pessoas que aprendam a dialogar a partir de suas tradições religiosas na direção das demais tradições. Uma soteriologia ecológica, como a sonha Susin, supõe uma noção do real perigo que corremos todos, ricos e pobres, espiritualistas e ateus, cristãos e candomblezeiros. E olhar juntos para o mesmo horizonte é o começo da salvação.

\section{Em busca da terra habitável: uma morada queer}

Um dos dias do citado Simpósio de Belo Horizonte teve por lema e desafio "Pensar o agir das igrejas". Um de seus fóruns intitulava-se "Comunidades cristãs e dispersão das trajetórias espirituais"7, e lá pudemos ouvir e analisar três experiências muito distintas, e que poderiam dar algumas pistas para o tema-eixo deste artigo: Arnd Bünker (Münster) deu seu testemunho sobre a prática comunitária das comunidades queer numa paróquia alemã; Sérgio Vasconcelos (Unicap, Recife) apresentou aspectos do sincretismo ou da dupla pertença religiosa afro-católica na região de

7 Dele participei como especialista (resource person) na área do diálogo inter-religioso. 
Recife; e Denis Villepelet (Paris) ${ }^{8}$ expôs os desafios da Igreja Católica francesa, cada vez mais identificada com comunidades de anciãos distantes do interesse e dos questionamentos da juventude.

Como se sabe, o tema exposto por Arnd Bünker é extremamente delicado para o cristianismo, principalmente para a Igreja Católica: a existência de homossexuais no seio das igrejas e seu crescente desejo de plena visibilidade em suas respectivas comunidades de fé. Seriam as igrejas cristãs uma "terra inabitável" para seus filhos homossexuais? Quais são as regras de pertença à igreja? perguntava-se Bünker. É possível ser queer e católico ao mesmo tempo? Sim, respondia o jovem teólogo, se aceitarmos a ruptura entre identidade e pertença.

Para Bünker, os cristãos gays não são apenas objetos da pastoral ou tema da teologia (moral); eles são sujeitos na igreja e em todo o arco da teologia. Na realidade, o fulcro teórico da questão é a teoria queer, um desenvolvimento da teologia de gênero que desidolatriza a identidade sexual quando preconiza que o ser humano pode ter outras orientações sexuais (homo, hetero, trans). Ademais, a iniciativa das comunidades queer apresenta-se como alternativa à estrutura paroquial europeia, que gira em torno da família tradicional. Elas são comunidades de acolhida e diaconia de todos aqueles que não se sentem em casa na sociedade hodierna: anciãos, pessoas fora dos padrões de beleza, doentes e demais solitários da nova urbe.

O depoimento de Bünker traz à luz do dia o desafio queer. Ainda há muito a refletir sobre a inclusão/exclusão de pessoas assumidamente cristãs que também assumam uma vida amorosa não heterossexual. Embora a religião cristã pregue o respeito e defenda a acolhida dos homossexuais em seu seio, a vida sexual dessas pessoas ainda é vista como disfuncional, anormal ou pecaminosa. Por outro lado, a recente e crescente visibilidade dos cristãos gays sugere que a identidade nunca é cabalmente definível, mas dá-se no processo, numa constante rede de pessoas. Se antes até se falava de uma antropologia de identidades, a recente retomada da utopia de uma terra habitável exige das religiões - e isto é bem mais difícil no

8 Denis Villepelet é Diretor do Instituto Superior de Pastoral Catequética do Instituto Católico de Paris, onde leciona Teologia da Catequese. 
caso dos monoteísmos ocidentais - uma aceitação de distintos níveis de pertença (sexual, étnica, social, cultural, de gênero) que, de resto, sempre existiram, mas poucas vezes foram assumidos por princípio. As vivências ${ }^{9}$ são provisórias, nômades, precárias. Eis aí uma primeira pista para os que pensamos ser possível outro modo de tornar habitável a nossa Mãe Terra.

\section{Na casa do Abbá há tantas moradas habitáveis}

O provisório, o nômade e o precário não desafiam as religiões somente na dimensão sócio-política dos fluxos migratórios e seus percalços (migrações internas, imigrações ilegais, refugiados políticos) ${ }^{10}$. O testemunho proporcionado por Sergio Vasconcelos, que narrou sua aproximação ao fenômeno do hibridismo afro-católico no nordeste brasileiro, trouxe à tona os fluxos religiosos e culturais (VASCONCELOS, 2005, p. 287-295). Ele salientou o espírito de diálogo que o norteou e o consequente esforço para compreender seu significado, embora reconhecendo que cada sincretismo é único. Da lentidão e gradualidade de tal processo é prova a própria experiência de Vasconcelos, que levou oito anos de relações de amizade na comunidade até descobrir que seus vizinhos eram do candomblé.

Com a autoridade de quem fez a experiência, mas também domina as categorias da teologia e das ciências da religião, Vasconcelos propôs uma categoria ioruba fundamental para entender a lógica do sincretismo: a força vital ou o axé. Há um desejo de fundo na comunidade (terreiro) de participar dessa força. Daí a facilidade de fazer sincretismo, já que o axé está em tudo e permeia todas as coisas. É por isso que tudo "vira casa nossa”. O "habite-se" não é negado a ninguém, caso queira participar.

9 Tenho preferido, ultimamente, o termo "vivências" a "pertenças". Este último parece impor um nível de comprometimento que nem sempre é real ou factível na urbe cosmopolita. Cf. meu recente livro, No espírito do Abba: fé, revelação e vivências plurais. São Paulo: Paulinas, 2008.

10 Sobre a pesquisa e os trabalhos humanitários desenvolvidos a esse respeito, veja, por exemplo, a excelente rede internacional de Centros de Estudos Migratórios mantida pela Congregação dos Missionários de São Carlos (escalabrinianos) em vários países. 
A partir dessas premissas, Vasconcelos levantou duas questões bastante instigantes com respeito à chamada "inculturação" e ao pretendido "diálogo inter-religioso":

1. O que seria a tal inculturação para as culturas afro? Pois, afinal, o que a igreja está propondo somente agora já é feito há séculos pelos negros e isso é chamado de sincretismo.

2. Fala-se hoje de diálogo entre cristianismo e religiões de origem africana. Já é um avanço, pois foram necessários quase 500 anos para reconhecer o candomblé como religião. Entretanto, em que termos fazer tal diálogo, uma vez que $90 \%$ dos membros do candomblé já é católico?

Vasconcelos tem razão quando afirma a grande sensação de liberdade que envolve essas múltiplas experiências que vão fazendo parte da normalidade. "Não nos sentimos mais clandestinos", desabafava alguém entrevistado pelo autor. E ao jogo da teologia não cabe nenhuma mudança radical de propósitos; ela deve continuar fazendo o de sempre: ajudar as pessoas a construir sentido em suas vidas, a erguer suas tendas com redes de novas interações humanas.

É claro que a politerminologia que ronda a área poderia suscitar o oposto de uma terra ou de um "terreiro" habitável: inculturação, interculturalidade, inreligionação, hibridismo, sincretismo, trânsito religioso, dupla pertença e múltiplas vivências, e assim por diante. Mas como a (re) criação de uma terra habitável não é labor de gabinete, vai ficando muito clara a importância de deixar os verdadeiros sujeitos serem sujeitos, mesmo que o preço seja a perda das idéias claras e distintas. Como dizia Vasconcelos em feliz formulação: "A teologia que leva em conta o sujeito gagueja por honestidade intelectual".

Os desafios aqui subentendidos ou que demandam novas discussões não são poucos. Há quem opine que só é possível falar de dupla pertença, uma vez que a questão cultura-religião jamais se resolverá. Por isso, propugnar algo semelhante a uma inculturação pode significar, em certos ambientes, uma variável platônica na medida em que se pretenda que um núcleo intocado vá ao encontro de toda cultura.

Creio que o debate não deve disfarçar a seguinte questão: o que há de positivo, de complexo e de criativo nas construções sincréticas 
afro-católicas? E o que há de preconceituoso ou simplesmente equivocado nos estudos que se realizaram sobre o assunto? Como já mencionei em outras ocasiões ${ }^{11}$, muitas explicações desse fenômeno já foram descartadas pela comunidade científica. Por exemplo, a tese do sincretismo como máscara colonial para driblar a dominação; a hipótese do sincretismo apenas como estratégia de resistência; a sinonímia com justaposição (Roger Bastide), colcha de retalhos, bricolagem (Lévi-Strauss) ou aglomerado indigesto (que até hoje dá o tom dos pronunciamentos de teólogos católicos a respeito), pois, não explicam os casos em que a religião permanece como um todo integrado; ou ainda, o reducionismo de se ver o sincretismo num arco de bipolaridades do tipo pureza versus mistura, separação versus fusão, etc.

Para P. Sanchis, o sincretismo é "um processo tendencialmente universal dos grupos humanos quando em contato com outros: a tendência a utilizar relações apreendidas no mundo do outro para ressemantizar realidades e relações do seu próprio universo"12. Todavia, além de tendência, Sanchis o vê como "princípio dinâmico de ordenamento e de transformação", que configura "um processo que se cria a si próprio, tanto quanto cria o seu produto, nunca acabado" (SANCHIS, 1998, p. 159). No Brasil contemporâneo, esse processo tem se desdobrado em sincretismo "de ida", fruto de um encontro desigual de civilizações (o escravismo negro e indígena nas Américas); e sincretismo "de volta", que vai da religião efetivamente praticada em direção às raízes atávicas do indivíduo (negros católicos em busca de suas raízes africanas olvidadas).

Por outro lado, há quem diga que, por exemplo, candomblé e catolicismo são suplementares, coexistentes e complementares. O catolicismo oferece o limite moral (separação entre o bem e o mal) e a possibilidade de transcendência; o candomblé articula um discurso para o mundo social, as relações interpessoais e a dimensão psíquica, tendo nos orixás um "léxico para a introspecção". O diálogo entre ambas as tradições, no interior de um mesmo indivíduo, é feito em termos de "alternância de códigos".

${ }_{11}$ Cf. SOARES, A. M. L. Sincretismo religioso y desafíos a la teología de la liberación. Alternativas, v. 11, n. 27, p. 136, 2004. Ou: SOARES, A. M. L. Interfaces da revelação. São Paulo: Paulinas, 2003.

12 Essa é, para Sanchis, "uma tendência das sociedades humanas a entrar num processo de redefinição da própria identidade quando confrontadas ao sistema simbólico do outro” (SANCHIS, 1998, p. 155). 
Em alguns depoimentos que recolhi quando preparava minha tese doutoral, diziam-me que o catolicismo (cristianismo) era a base mínima indispensável que preparava o povo para os vôos mais altos do candomblé.

Pois bem, como ler tudo isso teológica e eclesiologicamente? Em nosso modo de entender, os teólogos cristãos fariam bem se levassem a sério o fato de estarmos sempre às voltas com uma fé sincrética. Uma teologia (fundamental e dogmática) mais arejada não se furtará a reconhecer, com o auxílio das ciências da religião, a condição e os condicionamentos radicalmente humanos do acesso à fé cristã (e a qualquer outra, afinal). Dizer que nossa fé é "fé sincrética" apenas significa que ela é absoluta em sua opção por alguns valores fundamentais (que estão em jogo na escolha aparentemente contraditória dos significantes religiosos) sem deixar de ser relativa nos resultados efetivamente atingidos, sempre ideológico-sincréticos. Falo de "fé sincrética" apenas para chamar a atenção sobre o modo mesmo de uma fé se concretizar, pois só existe fé nas misturas de nossas práticas cotidianas.

Se quisermos chamar esse dia-a-dia de nossa fé de "fé inculturada" também pode ser, desde que percebamos a diferença de trajeto ou o ponto de vista de onde se observa a invenção religiosa popular. A comunidade eclesial propõe-se a inculturar ou inreligionar a mensagem evangélica; o povo responde, acolhendo a "novidade" de acordo com suas reais estruturas significativas.

Dizer fé inculturada é pressupor um dado transcendente, um valor absoluto finalmente garantido pelo Ser Absoluto acolhido na fé. Presumindo que tal verdade esteja sob sua custódia, a igreja dá o passo de comunicá-la para além das fronteiras originais. Mas quando afirmo a fé sincrética saliento que o sopro do Espírito já esteja agindo nas demais tradições culturais antes, contra ou mesmo apesar do contato com as comunidades cristãs.

O povo de santo "inreligiona" o que pode ou quer acolher da Tradição cristã. De fato, muitos praticantes da tradição dos orixás, da umbanda e de outras variáveis religiosas de nossa herança africana sentem-se sinceramente católicos. Acolheram em suas tradições de origem o enxerto cristão, expurgaram o que lhes pareceu desumano ou sem-sentido, 
misturaram o que não tinha muita importância, e mantiveram o que julgaram positivo e enriquecedor para sua própria cosmovisão ${ }^{13}$.

\section{As jovens moradas habitáveis circulam web afora}

Voltando aos depoimentos instigantes do mencionado Simpósio França-Alemanha-Brasil, tivemos a oportunidade de acolher uma terceira experiência, ainda não muito sentida em ambientes latino-americanos (embora já definitivamente presente nas metrópoles existentes também entre nós). Relatou-a Denis Villepelet e fez-nos voltar para outro ângulo da discussão: a dispersão das trajetórias espirituais numa diocese parisiense em que $60 \%$ da população ainda se diz cristã, mas apenas $2 \%$ querem participar da comunidade. A realidade das novas cidades européias é de uma terra habitada por homens e mulheres que trabalham, com grande número de oriundos da África que seguem o islamismo. Os mais jovens muitas vezes submetem-se a três horas de viagem para ir trabalhar. $\mathrm{O}$ resultado na prática religiosa é que a comunidade cristã é constituída por anciãos na faixa dos 60 anos, enquanto a juventude procura bem-estar a seu modo e se deixa fascinar pelo apelo new age.

Villepelet partiu do pressuposto de que religião é questão de pertença ou de identidade. Por isso, enucleou sua reflexão em torno de três provocações:

- De início, é preciso aceitar que a noção de igreja como comunidade paroquial está desaparecendo para sempre. Teremos de aprender a lidar com isso.

- Daí decorre que a noção de comunidade esteja agora em questão: inserida em uma sociedade a ela indiferente, a igreja tende a demarcar sua área com normas, reúne-se em grupos por afinidade ou vive a nostalgia da noção de bairro e de família. Como descobrir, então, o que significa fazer "comunidade fraterna", ser igreja?

13 Para os últimos dois parágrafos, ver, por exemplo, SOARES, A. M. L. Interfaces da revelação. São Paulo: Paulinas, 2003. p. 246. Ou: SOARES, A. M. L. No espírito do Abba: fé, revelação e vivências plurais. São Paulo: Paulinas, 2008. p. 102-104. 
- Por último, qualquer que seja o perfil dessa nova comunidade, ela deve se caracterizar por não fugir dos desafios. Um deles, segundo Villepelet, é a Internet.

Embora a questão da web mereça seguidos e constantes aprofundamentos, não resta dúvida de que haja recursos muito positivos nessa nova "rede" de comunicação. Ouvi, certa vez, de uma professora de comunicação que a Internet é o contrário da "paranoia"; ela é uma pronoia. Ou seja, em vez de imaginar, doentiamente, que alguém está me perseguindo, uma das utopias dessa nova proposta de uma terra por todos habitável é que alguém, a qualquer momento, vai me ajudar. Ademais, o conceito de "comunidade virtual" (que não se confunde com os milhões de chats espalhados pelo mundo afora) merece uma atenção cada vez maior de nossa parte, pois nada mais é do que um novo degrau na histórica e contínua busca humana de expansão de seu corpo físico. A seu tempo, também cumpriram tal função as pinturas rupestres, as pirâmides, os papiros, o livro, a invenção da imprensa, o cinema, o telefone e a televisão.

O relato de Villepelet suscita uma conclusão bem marcante e evangelicamente positiva. Graças ao rechaço dos jovens franceses - e de tantos jovens pelo mundo afora, sejam eles cibernautas ou apenas garotos descobrindo o amor sem a mediação de estruturas eclesiásticas eivadas de signos inadequados —, o fato é que a igreja católica francesa está redescobrindo algo comum a tantas outras igrejas em similar situação: a sensibilidade para a fraqueza. O centro da igreja está-se desfazendo num policentrismo e ela se vê cada vez mais pobre, marginal, excluída. O que está prestes a renascer após essa era glacial poderá ser para todos nós ocasião de graça.

\section{Como contribuirão as religiões para uma terra habitável?}

Os três depoimentos supracitados dão o que pensar, sobretudo porque provenientes de pessoas franca e decididamente cristãs. Eles poderiam provir do seio de qualquer outra religião, embora sejamos mais sensíveis no Ocidente aos exageros oriundos dos monoteísmos históricos. 
Retomando-os agora, à luz do tema geral da busca de uma terra habitável, podemos destacar três insights que, por sua vez, não eliminam nem inibem outras possíveis abordagens. É uma breve amarração (talvez, provocação), cujos principais itens seguem abaixo.

Fala-se muito de catolicidade em nossas comunidades cristãs em crise - é preciso salvaguardá-la, redescobri-la, iluminá-la, etc. Mas poderíamos perguntar, então: onde está a catolicidade dessas/nessas três experiências/testemunhos partilhadas acima? Para dizê-lo segundo a Escola Joânica, "No lar de meu Pai muitos podem viver" (Jo 14,2). Parece incrível, mas o conceito de (a nota da) catolicidade amplia-se aí para contemplar uma pluralidade de experiências que têm em comum o encontro com Jesus de Nazaré. Pode ser que nem todas geraram ou gerarão o seguimento strictu sensu, mas cruzaram com Jesus no caminho (de Emaús?). Enfim, a catolicidade não é nem poderá ser nunca uma propriedade da instituição igreja católica. Mas será sempre uma qualidade desejável na terra onde habitarmos.

O mencionado Vasconcelos reforçava essa direção em sua linha argumentativa, ao recordar-nos de que a igreja é católica porque já vive escatologicamente a salvação. Assim, nenhuma configuração histórica do cristianismo seria normativa. A bem da verdade, poderíamos retrucar que, se a igreja é apostólica, isso é normativo. No entanto, quem decidiria qual comunidade é fiel?

A terra habitável cristã não pode ser uma terra habitável só por cristãos, nem pensada apenas por cristãos. Ela tem de ser inclusiva, amorosamente inclusiva, ou nem será cristã. Precisamos ter presente alguns critérios consensuais, ou não faremos caminho juntos como cristãos. No nosso caso, temos a Tradição (com T maiúsculo), a Escritura e o cimento da experiência da comunidade. As três iluminam-se reciprocamente. A Tradição sozinha ou correndo na paralela degenera em tradicionalismo; a sola Scriptura pode virar literalismo/fundamentalismo (ou, no mínimo, exegese sem hermenêutica); a simples experiência comunitária do presente, por si só não vai além de um clube ou, como se diz hoje em dia, de uma tribo urbana.

Neste ponto, é preciso chamar a atenção para a experiência (humana) de Deus. É um ganho da teologia contemporânea a redescoberta de que 
a revelação de Deus é um processo histórico, com momentos/dimensões que têm seu sentido próprio (Dei Verbum 15: a pedagogia divina), mas não são definitivas. Nesse processo, o povo bíblico (autores e comunidades leitoras) sempre procurou modular em linguagem humana o sopro e as ressonâncias do Espírito Santo. Daí vem a força (e a fraqueza) do umbral cristão: este depende intrinsecamente de uma experiência ineludível que só tem sentido se o indivíduo a fizer por si mesmo. Nem é garantido que o resultado deva necessariamente configurar-se como uma comunidade nitidamente cristã (ao menos, nos moldes em que as podemos descrever hoje). E mesmo que o fosse, isso não eliminaria a inevitável ambigüidade da tradução prática deste encontro, ou seja, da vida cristã. É por isso que podemos dizer que nossa condição humana empurra-nos ao sincretismo. O que requer do cristianismo uma contínua crítica e autocrítica do statu $q u o$, de suas realizações pastorais, de suas formulações teórico-teológicas, e assim por diante.

Uma segunda consideração. Algo que se pode vislumbrar nos testemunhos descritos acima - ao menos na luta dos queers cristãos por reconhecimento e acolhida e na decisão dos que, oriundos da espiritualidade afro, querem acolher o catolicismo sem repudiar sua tradição de berço - são as variações de uma experiência de amor. Podemos chamá-los de evento da graça, ou da gratuidade, ou da espiritualidade. E onde há amor, repetia-nos o saudoso professor Hermilo Pretto, não há pecado ${ }^{14}$. Por que a comunidade de Arnd Bünker teima em ter a missa, a eucaristia e a reunir-se como católicos queer? É um caso de amor por essa velha senhora, a igreja, ou pelas utopias que ela suscita mesmo quando não as busca com coerência. Por que o povo de santo (do candomblé) não desgruda da igreja? Talvez tenha razão o octogenário frei Boaventura Kloppenburg, antigo inimigo figadal das religiões mediúnicas nas décadas anteriores ao

\footnotetext{
14 Há quem discorde dessa última afirmação, porque entende que só quando há amor é possível pecar, pois somente quem ama reconhece o pecado. Não vejo, ao menos do ponto de vista cristão, contradição alguma, mas apenas ênfases complementares em nossas perspectivas. Quem ama está mais alerta ao dano que se comete contra as pessoas; mas o ato amoroso em si não é pecaminoso, embora, pela nossa própria concupiscência, no sentido que K. Rahner deu a esse termo, ele sempre será um gesto ou atitude mesclado, ambíguo.
}

Rev. Pistis Prax., Teol. Pastor., Curitiba, v. 8, n. 1, p. 129-149, jan./abr. 2016 
Concílio Vaticano II: São aqueles que mais amam a igreja católica aqui no Brasil, embora sejam os que mais apanham dela.

O certo é que a história da revelação divina é uma história de amor entre Deus e a humanidade, e tem por tálamo a história. Porque, como dizia mestre Juan Luis Segundo, faz parte da revelação também a maneira como os povos foram chegando aos dogmas, isto é, em meio a avanços e retrocessos, erros e acertos, gestos amorosos e pecaminosos. Só assim podemos entender como o conjunto de "revelações" auto-excludentes recolhidas e mantidas em contigüidade pelos redatores bíblicos componha hoje a "Palavra de Deus" (SEGUNDO, 2000). Em suma, outras variáveis possíveis, a partir de uma mesma intuição original, têm lugar na Tradição cristã. É o caso da fé abrâmica a que hoje se reportam tanto judeus quanto cristãos e muçulmanos. E se assim é, com todo o respeito ao mesmo Segundo, estou certo de que o sincretismo é a história da revelação em ato, pois o vejo como o caminho real da pedagogia divina em meio aos povos dessa Terra.

Nossa terceira consideração inspira-se no livro de Adolphe Gesché, Dieu pour penser ${ }^{15}$. Ou seja, Deus como condição de possibilidade para pensar qualquer coisa. A teologia é assim "ciência dos excessos", que pensa o impensável, vai até os limites do pensamento, e tem em Deus a metáfora para esse limite. Se, de um lado, como dizia K. Rahner, toda teologia é antropologia, de outro, ela pretende estudar Deus mesmo, Deus em si, pondo-se no lugar Dele. É uma ousadia, da qual também não queremos abrir mão.

Pois bem, esse insight de Gesché poderia nos ajudar a considerar a "teima" dos "sincretistas" em permanecer no colo do cristianismo: o problema é que eles não querem largar nenhum dos dois amores (catolicismo e candomblé, por exemplo). Querem os dois; são contra a monogamia. Os três testemunhos ouvidos (Bünker, Vasconcelos e Villepelet) mostram que ainda estamos longe do limite. Pode ser desesperador para a antiga escolástica (pois, como dizia Vasconcelos, "quando a gente narra, desconcerta"), mas é fantástico para a mística de ontem, hoje e sempre. É fascinante (sem deixar de ser tremendo) para quem está vivendo

${ }^{15}$ A coleção foi publicada por Paulinas Editora com o título Deus para pensar. 
a experiência. Porém é um saber experiencial que gera um novo poder oriundo dessa nova experiência. E isso é conflitivo, pois, o saber sempre foi uma forma de administração do poder e esses novos sujeitos aqui testemunhados (queers, afrodescendentes, juventude do século XXI) provêm de um não-poder. Querem ter casa própria — nem que seja no ciberespaço — e não aceitam morar de favor.

\section{Modesta conclusão - pois a terra a ser habitada é uma grande lona circense}

Como se vê, não ousamos palpitar sobre como as religiões deveriam contribuir para uma terra habitável. Nem quisemos debater com os que se arriscaram a tanto. ${ }^{16}$ Mas refletir sobre algumas brechas e vazamentos no complexo cristão-católico pode, com certeza, contribuir para uma ampliação do diálogo entre as religiões e um amadurecimento na luta por uma casa comum e habitável.

Isto posto, à guisa de interrupção da reflexão, retomamos algumas idéias que permearam este artigo e poderiam consistir em três pequenas conclusões provisórias:

1) As três experiências nos sensibilizam a uma acolhida generosa. Em sua inevitável ambivalência, e sem querer ser ingênuos diante dos pecados de nossa história cristã, é impossível não vê-las também como casos de amor. O silêncio obsequioso prévio à palavra segunda da teologia é mais do que oportuno no julgamento dessas experiências; afinal, de certa forma, Jesus também foi queer, pois seu comportamento causou estranheza. Enfim, "Ele também era interidentidades" (Estermann).

2) As experiências testemunhadas dão conta de novos sujeitos assumindo o leme, dentro e fora do cristianismo deste novo século. É um acontecimento em que emergem o parcial, o provisório e o conflitivo. Como, de resto, em qualquer acontecimento da história.

${ }^{16}$ Ver, por exemplo: MAÇANEIRO, M. Religiões, Ecologia e sustentabilidade. In: SOTER, 21, 2008, Belo Horizonte. Anais do Congresso Anual da Sociedade de Teologia e Ciências da Religião. São Paulo: Paulinas, 2008. Também MAÇANEIRO, M. Religiões \& Ecologia: cosmovisão, valores, tarefas. São Paulo: Paulinas, 2011. 
Entretanto, sabemos que a teologia é sempre parcial e não se pode procurar totalidades rápidas. Os teólogos teremos de continuar peregrinando, de tenda em tenda, na provisoriedade, porém animados porque nosso próprio corpo peregrino já é templo e morada do Espírito.

3) Finalmente, essas experiências mais (para alguns) ou menos (para outros) desconcertantes nos põem diante do desafio de uma nova catolicidade a ser construída. A terra habitável terá de ser ecologicamente católica (universal) em seu melhor sentido. E as perguntas multiplicam-se: como fazer comunidade em cada um desses contextos? Que significa hoje fraternidade e sororidade? Como lidar com o medo diante do novo, principalmente desses sujeitos emergentes? Algumas pistas muito ricas têm sido sugeridas nos mais diversos areópagos hodiernos. Houve quem apelasse para o recente jargão da física moderna e propusesse que as energias dissipativas do fenômeno que estamos chamando de "dispersão das trajetórias espirituais" afastam-se para se reagruparem em novas configurações. E a experiência de Jesus bem poderia ser capaz de reorganizar as energias. Por outro lado, a partir de sua experiência parisiense, Villepelet insistia em um dado importante: o caos é contínuo; já é hora de aceitarmos que estaremos sempre em crise e não há situação ideal de equilíbrio. E talvez o equilíbrio mais difícil seja a sutil distinção proposta por J. Estermann, da qual nos apropriamos para interromper (sem concluir) estas considerações: ao falar de catolicidade necessária a uma terra/comunidade de viventes que se queira habitável, é preciso distinguir entre o "tudo cabe" (eclético refrão pós-moderno) e o "todos cabem” (este, sim, utopicamente evangélico e evangelicamente utópico).

Com certeza, o diálogo intra e inter-religioso que supõe a concretização dessa utopia está apenas começando. E Oxalá continue gerando bons frutos pelos caminhos da vida. 


\section{Referências}

BOFF, L. Ética e espiritualidade planetárias. SOTER - Sociedade de Teologia e Ciências da Religião (Org.). Sustentabilidade da vida e espiritualidade. São Paulo: Paulinas, 2008. p. 173-190.

BÜNKER, A. La dynamique de l'identité et de l'appartenance: une expérience. In: MÜLLER, H.; VILLEPELET, D. Risquer la foi dans nos sociétés. Paris: Karthala, 2005. (Coll. Chrétiens en Liberté). p. 281-286.

CONGRESSO ANUAL DA SOCIEDADE DE TEOLOGIA E CIÊNCIAS DA RELIGIÃO - SOTER, 21., 2008, Belo Horizonte. Anais... São Paulo: Paulinas, 2008. Disponível em: <http://ciberteologia.paulinas.org.br/ciberteologia/index. php/livrodigital/soter/>. Acesso em: 5 dez. 2014.

GESCHÉ, A. Coleção Deus para pensar. São Paulo: Paulinas, 2002-2008.

GRAY, J. Cachorros de palha: reflexões sobre humanos e outros animais. Rio de Janeiro: Record, 2005.

MAÇANEIRO, M. Religiões \& Ecologia: cosmovisão, valores, tarefas. São Paulo: Paulinas, 2011.

MÜLLER, H.; VILLEPELET, D. Risquer la foi dans nos sociétés: églises d'Amérique Latine et d'Europe en dialogue. Paris: Karthala, 2005. (Coll. Chrétiens en Liberté).

MURAD, A. T. Paradigma ecológico: gestão e educação ambientais. In: SOTER - Sociedade de Teologia e Ciências da Religião (Org.). Sustentabilidade da vida e espiritualidade. São Paulo: Paulinas, 2008. p. 39-62.

SANCHIS, P. Sincretismo e pastoral de massas. In: LESBAUPIN, I. (Org.). Igreja; comunidade e massa. São Paulo: Paulinas, 1998. p. 151-198.

SEGUNDO, J. L. O homem de hoje diante de Jesus de Nazaré. v. 1: Fé e ideologia. São Paulo: Paulinas, 1985.

SEGUNDO, J. L. O dogma que liberta. 2. ed. São Paulo: Paulinas, 2000.

SOARES, A. M. L. Interfaces da revelação: pressupostos para uma teologia do sincretismo religioso. São Paulo: Paulinas, 2003. 
SOARES, A. M. L. Sincretismo religioso y desafíos a la teología de la liberación. Alternativas, v. 11, n. 27, p. 122-138, 2004.

SOARES, A. M. L. No espírito do Abba: fé, revelação e vivências plurais. São Paulo: Paulinas, 2008.

SOTER - Sociedade de Teologia e Ciências da Religião (Org.). Sustentabilidade da vida e espiritualidade. São Paulo: Paulinas, 2008.

SUSIN, L. C. Mãe Terra que nos sustenta e governa: por uma teologia da suste tabilidade. In: SOTER (Org.). Sustentabilidade da vida e espiritualidade. São Paulo: Paulinas, 2008. p. 191-214.

VASCONCELOS, S. S. D. Le syncrétisme afro-catholique: une expérience. In:

MÜLLER, H.; VILLEPELET, D. Risquer la foi dans nos sociétés: églises d'Amérique Latine et d'Europe en dialogue. Paris: Karthala, 2005. (Coll.: Chrétiens en Liberté). p. 287-295.

Recebido 10/03/2014 Received: 03/10/2014

Aprovado: 24/11/2014 Approved: 11/24/2014 